\title{
Using of Acetylacetone-formaldehyde Reagent in Spectrophotometric Determination of Aniline in Various Water Samples
}

\author{
Nabeel S. Othman ${ }^{1 *}$; Safa A. Al- Zakaria²; Muna S. Abdulla ${ }^{3}$ \\ ${ }^{1,2,3}$ Department of Chemistry, College of Science, University of Mosul, Mosul, Iraq
}

Email: ${ }^{1 *} \underline{\text { nsn20002004@yahoo.com, }}{ }^{2}$ safa_ahmed2017@yahoo.com, ${ }^{3}$ munasub@yahoo.com

(Received October 17, 2019; Accepted January 06, 2020; Available online June 01, 2020)

DOI: 10.33899/edusj.2020.126192.1022, (c) 2020, College of Education for Pure Science, University of Mosul.

This is an open access article under the CC BY 4.0 license (http://creativecommons.org/licenses/by/4.0/).

\begin{abstract}
A simple and accurate spectrophotometric method for the estimation of aniline in various water samples was done. The method was based on the condensation reaction of acetyl acetoneformaldehyde (AC-FA) reagent with aniline. to produce a yellow colored product, with maximum absorption at $417 \mathrm{~nm}$, which has good stability at room temperature and it is very soluble in water (the medium of reaction). Beer's law is applied in the concentration range of 2.5 to $50 \mu \mathrm{g}^{-\mathrm{ml}^{-1} \text { of }}$ aniline with a molar absorptivity $3.864 \times 10^{3} 1 . \mathrm{mol}^{-1} . \mathrm{cm}^{-1}$ and Sandell's sensitivity index 0.0241 $\mu \mathrm{g} . \mathrm{cm}^{-2}$, a relative error of -0.51 to $+4.15 \%$ and a relative standard deviation of \pm 0.78 to $\pm 1.28 \%$ depending on the concentration level. The study also included the effect of organic compounds on the recovery of aniline in water samples. Aniline is the simple type of primary aromatic amines as it enters into many industrial fields and is considered as an important material. Aniline regarded as major pollutant of water, thus, its estimation was studied in different samples of water such as river, tap and Zamzam well waters.
\end{abstract}

Key words: aniline, acetylacetone-formaldehyde reagent, determination, waters.

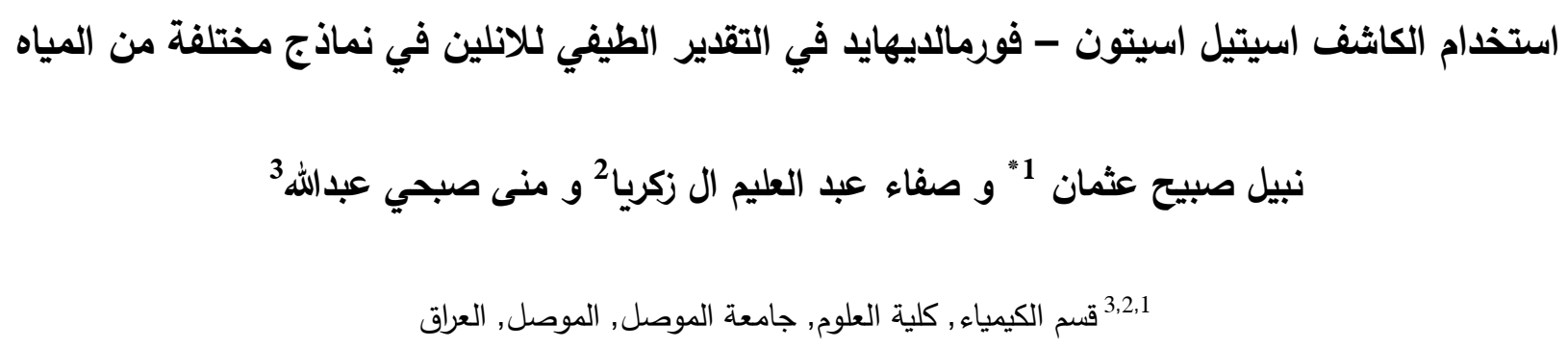


اجريت طريفة طيفية بسيطة وسهلة لتقدير الانلين في نماذج مختلفة من المياه .الطريقة تعتمد على تفاعل تكثيف للكاشف اسيتيل اسيتون- فورمالديهايد مع الانلين ويتكون ناتج اصفر، يمتلك اقصى امتصاص عند 417 نانوميتر ، يتصف الناتج

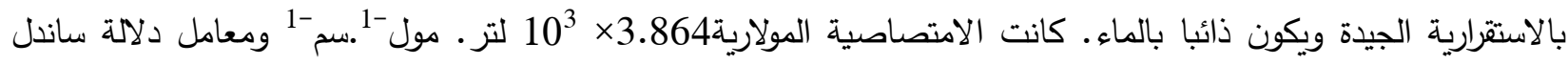

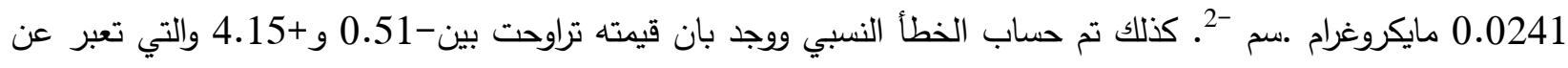

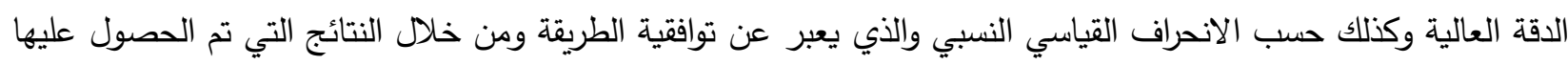

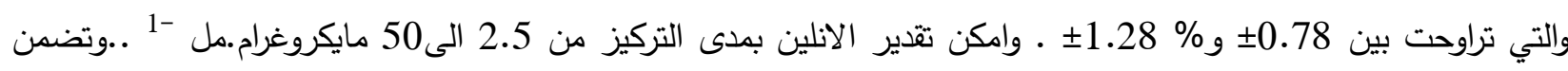

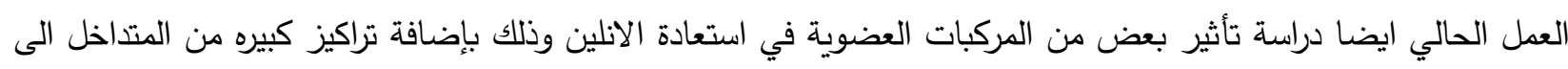

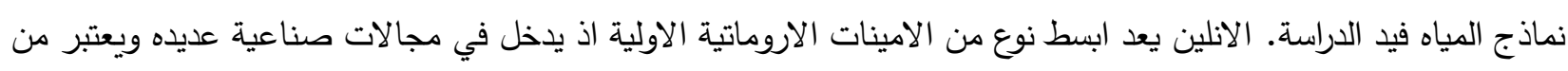
المواد المهمة .الانلين يعتبر من الملوثات الرئيسية للمياه ـ الطريقة طبقت في تقدير الانلين في نماذج مختلفة من المياه وتضمنت التان مياه النهر والأسالة وبئر زمزم

الكلمات الدالة: الانلين وكاشف الاسيتيل اسيتون -فورمالديهايد والتقدير والمياه

\section{Introduction}

Aniline is an organic compound that has the formula $\mathrm{C}_{6} \mathrm{H}_{5} \mathrm{NH}_{2}$. It consists of amino group which attached to one position of a phenyl group, it is the typical simple aromatic amine. The main uses of aniline are in the manufacture of precursors to polyurethane and other industrial chemicals. Like most volatile amines, aniline has the odor of rotten fish ${ }^{(1)}$. Aniline is used to produce an important chemical compounds that are used in manufacturing of rubber, it is also used in the preparation of phenylene diamine and diphenylamine, which are the most additives to rubber. Aniline is an important chemical substance used in manufacture the herbicides and fungicides that are used in extermination weeds and organisms having a destructive action to plants. Aniline and its derivative are essential in the formation of various dyes after diazotisation and coupling with other compounds such as phenol, derivative of phenol or activated carbon ${ }^{(2-5)}$.In the late 19th century, acetanilide and phenacetin(is a pain-relieving and fever-reducing drug) which are the more important derivatives of aniline emerged in manufacturing of pharmaceutical preparations as analgesic drugs, with their cardiac-suppressive side effects often countered or emitted by using $\underline{\text { caffeine }}^{(6)}$. Aniline and other amines may exist in the environment as an outcome of manufacturing discharge from various factories that use anilines as intermediates or as a product of the degradation of some herbicides. Several aromatic amines compounds are identified to be toxic and are suspected to be one of the causes of cancer $^{(7)}$ especially for the workers who are in contact with these compounds. Therefore these workers and also who work with pigment should be cautious.

Many techniques or methods have been used in determination of aniline in various samples. These methods include solid phase analytical derivatization $-\mathrm{GC}^{(8)}$, liquid phase microextraction-GC ${ }^{(9)}$, liquid- liquid - liquid -microextraction-HPLC ${ }^{(10-11)}$,solid phase extraction-HPLC ${ }^{(12)}$, UHPLC $^{(13)}$, and capillary electrophoresis ${ }^{(14,15)}$. Most spectrophotometric methods include either diazotization of amino group and coupling with a specific reagent such as :2,6-dihydroxybenzoic acid ${ }^{(5)}$ or 2methyl-8-hydroxyquinoline ${ }^{(16)}$, they may also include oxidative coupling reaction with other reagents such as $\mathrm{p}-\mathrm{N}, \mathrm{N}$-dimethylphenylenediamine in presence of sodium meta periodate as oxidizing agent ${ }^{(17)}$,quaiacol in presence of $N$-chlorosuccinimide ${ }^{(18)}$ and promethazine in presence of hypochlorite ion ${ }^{(19)}$.Charge transfer reaction is also used in the determination of aniline using $7,7^{\prime}, 8,8^{\prime}$ tetracyanoquinodimethane ${ }^{(20,21)}$. 
The literary survey shows that significant uses of the acetyl acetone - formaldehyde reagent were observed in the estimation of many primary amines containing drugs such as: pramipexole dihydrochloride ${ }^{(22)}$, some cephalosporins ${ }^{(23)}$, mono sopropylamine ${ }^{(24)}$, Baclofen ${ }^{(25)}$, midodrine hydrochloride $^{(26)}$ and some sulpha drugs ${ }^{(27)}$.

Aniline and derivatives are considered as major pollutant of water, thus, the proposed method has been applied in estimation of aniline in different samples of water such as river tap and Zamzam well waters.

\section{Experimental}

\section{Apparatus}

The absorbance measurements have been done by JASCOV - 630 UV / Vis spectrophotometer (Japan), with $1 \mathrm{~cm}$ matched glass cells. $\mathrm{pH}$ measurements have been done by using HANNA 211 $\mathrm{pH}$-meter.

\section{Materials and solutions}

All materials used in this work are of analytical grade except for aniline and acetyl acetone which need purification via distillation .

Aniline solution, $250 \mu \mathrm{g} \cdot \mathrm{ml}^{-1}$. After the purification of aniline by distillation, $10000 \mu \mathrm{g} \cdot \mathrm{ml}^{-1}$ aniline solution has been prepared by diluting $0.99 \mathrm{ml}$ of aniline to $100 \mathrm{ml}$ in a volumetric flask using distilled water(in presence of $5 \mathrm{ml}$ ethanol), then $2.5 \mathrm{ml}$ of above solution diluted to the mark of a $100 \mathrm{ml}$ volumetric flask to prepare $250 \mu \mathrm{g} \cdot \mathrm{ml}^{-1}$.

Acetylacetone-formaldehyde reagent. The preparation was comprised of mixing $3.9 \mathrm{ml}$ of freshly distilled acetyl acetone with $7.5 \mathrm{ml}$ of formaldehyde (36\%). After that $8 \mathrm{ml}$ of $0.2 \mathrm{M}$ sodium acetate and $17 \mathrm{ml}$ of $0.2 \mathrm{M}$ acetic acid were added. The resulting mixture was kept in a boiling water-bath for 5 minutes. The solution was left in room temperature for cooling and then the $\mathrm{pH}$ had been adjusted at 4.3 by adding diluted sodium hydroxide. Finally the volume was diluted to $100 \mathrm{ml}$ in a volumetric flask by adding distilled water. The AC-FA reagent was prepared daily ${ }^{(27)}$.

\section{Samples of Waters}

Different kinds of water are used in this study. They are Zamzam well water (a well in Kingdom of Saudi Arabia), river water from Tiger (a river in Mosul-Iraq) and tap water from the laboratory of chemistry in Mosul University (in Mosul -Iraq).

\section{General procedure and calibration graph}

The effect of the aniline concentration has been studied by transferring a liquid of aniline solution ( $250 \mu \mathrm{g} . \mathrm{ml}^{-1}$ ) into a $20 \mathrm{ml}$ volumetric flasks to covered the concentration from 2.5 to $50 \mu \mathrm{g}$. $\mathrm{ml}^{-1}$, and then $4 \mathrm{ml}$ of AC-FA reagent had been added, the mixture was left for 25 minute in water-bath at $40^{\circ} \mathrm{C}$. After that the volumes were completed to the mark with distilled water, the absorbance was read at $417 \mathrm{~nm}$ against the reagent blank. Beer's law has been applied from 2.5 to $50 \mu \mathrm{g}$ aniline / $\mathrm{ml}$ (Fig. 1). The molar absorptivity has been found to be $3.864 \times 10^{3} 1 . \mathrm{mol}^{-1} \cdot \mathrm{cm}^{-1}$. 


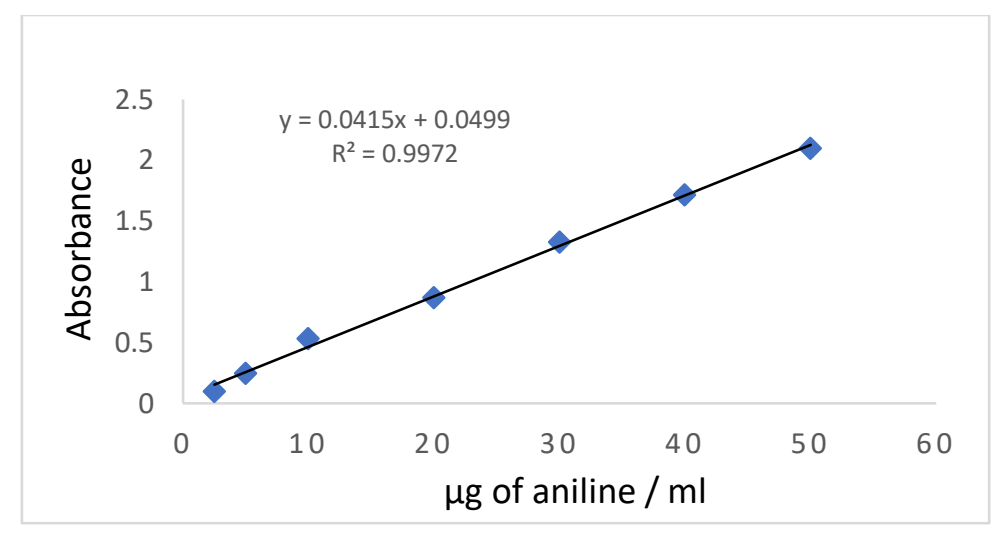

Fig. 1. Calibration Graph of Aniline Determination.

Some of the important analytical parameters of the present method have been illustrated in Table 1.

Table 1. Analytical Parameters of The Method .

\begin{tabular}{|c|c|}
\hline$\lambda \lambda_{\max }, \mathrm{nm}$ & 417 \\
\hline Reagent used & Acetyl acetone - formaldehyde \\
\hline Beer's law, $\mu \mathrm{g} . \mathrm{ml}^{-1}$ & $2.5-50$ \\
\hline Molar absorptivity factor, $\mathrm{I}_{\mathrm{mol}}{ }^{-1} \mathrm{~cm}^{-1}$ & $3.864 \times 10^{3}$ \\
\hline Temperature ${ }^{\circ} \mathrm{C}$ & 40 \\
\hline Regression equation & $\mathrm{y}=0.0415 \mathrm{x}+0.0499$ \\
\hline Slop & 0.0415 \\
\hline Intercept & 0.0499 \\
\hline $\mathrm{X}$ & Concentration in $\mu \mathrm{g} . \mathrm{ml}^{-1}$ \\
\hline Relative error, $\mathrm{RE} \%$ & -0.51 to $+4.15 \%$ \\
\hline Relative standard deviation, $\mathrm{RSD} \%$ & \pm 0.78 to \pm 1.28 \\
\hline Color of product & Yellow \\
\hline Stability, minutes & 60 \\
\hline
\end{tabular}

\section{Result and Discussion}

All the parameters that affected the intensity of the yellow products have been tested and the optimum state of each parameter has been selected, these parameters included: the optimum $\mathrm{pH}$ of acetyl acetone - formaldehyde reagent .Three $\mathrm{pH}$ (2, 4.3 and 6)of the final solutions of AC-FA reagent have been tested in the estimation of $400 \mu \mathrm{g}$ of aniline in $20 \mathrm{ml}$ total volume. The results indicated that $\mathrm{pH}=4.3$ was optimum $\mathrm{pH}$ which has been selected.

The quantity of AC-FA reagent has been also studied in this work. The results of the experiments indicated that the little amount of AC-FA reagent $(2$ or $3 \mathrm{ml})$ gave turbid solutions .An increase in the absorbance of the colored product was observed with increasing in the amount of the reagent. The results indicated that the volume of $4 \mathrm{ml}$ is the optimum volume and was fixed in the subsequent experiments. The effect of the surfactant has been studied by adding $3 \mathrm{ml}$ of various 
type including positive, negative and neutral types named CPS ,SDS and triton FX-100 respectively. There is no improvement in absorbance by adding these types. Therefore they have been canceled in the next experiments. An analytically important factor is the stability of the product (meaning the absorbance remains constant over time). The results in table 2 indicated that the yellow products produced from reaction of 10 and $20 \mu \mathrm{g} \cdot \mathrm{ml}^{-1}$ of aniline with AC-FA reagent in a final volume of $20 \mathrm{ml}$ have good stability for at least 1 hour

Table 2:The stability of the product.

\begin{tabular}{|c|r|c|c|c|c|c|c|c|}
\hline \multirow{2}{*}{ mg.ml $^{-1}$} & \multicolumn{7}{|c|}{ A/ Time , minute } \\
\cline { 2 - 9 } & $\begin{array}{c}\text { After } \\
\text { dilution }\end{array}$ & 5 & 10 & 20 & 30 & 40 & 50 & 60 \\
\hline 10 & 0.511 & 0.514 & 0.513 & 0.515 & 0.508 & 0.504 & 0.501 & 0.499 \\
\hline 20 & 0.868 & 0.867 & 0.865 & 0.887 & 0.884 & 0.874 & 0.872 & 0.871 \\
\hline
\end{tabular}

The diagram below shows the important reaction steps: The first step is the conformation of the AC-FA reagent and the second step is the link between the reagent component of AC-FA with aniline. The closure of the ring is produced to form a heterogeneous ring, nitrogen of aniline one of the ring's atoms ${ }^{(27)}$.

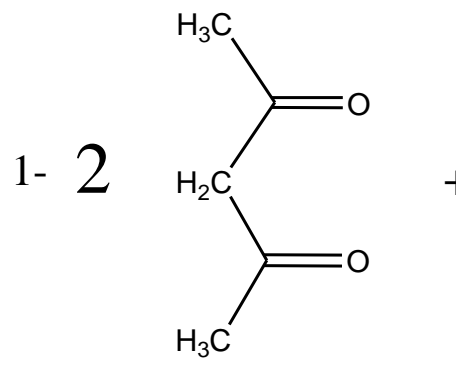

Acetylacetone

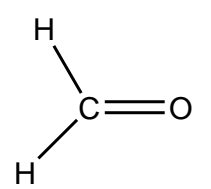

Formaldehyde<smiles>CCCCCCCC(C(C)=O)C(C(C)=O)C(C)=O</smiles>

Acetyl acetone-Formaldehyde 


\section{Estimation of Absorption Maximum}

AC-FA reagent was reacted with aniline to produce a yellow product. The absorption spectra in Fig. 2 shows that maximum absorption wavelength for AC-FA- aniline yellow product that was recognized to be $417 \mathrm{~nm}$.

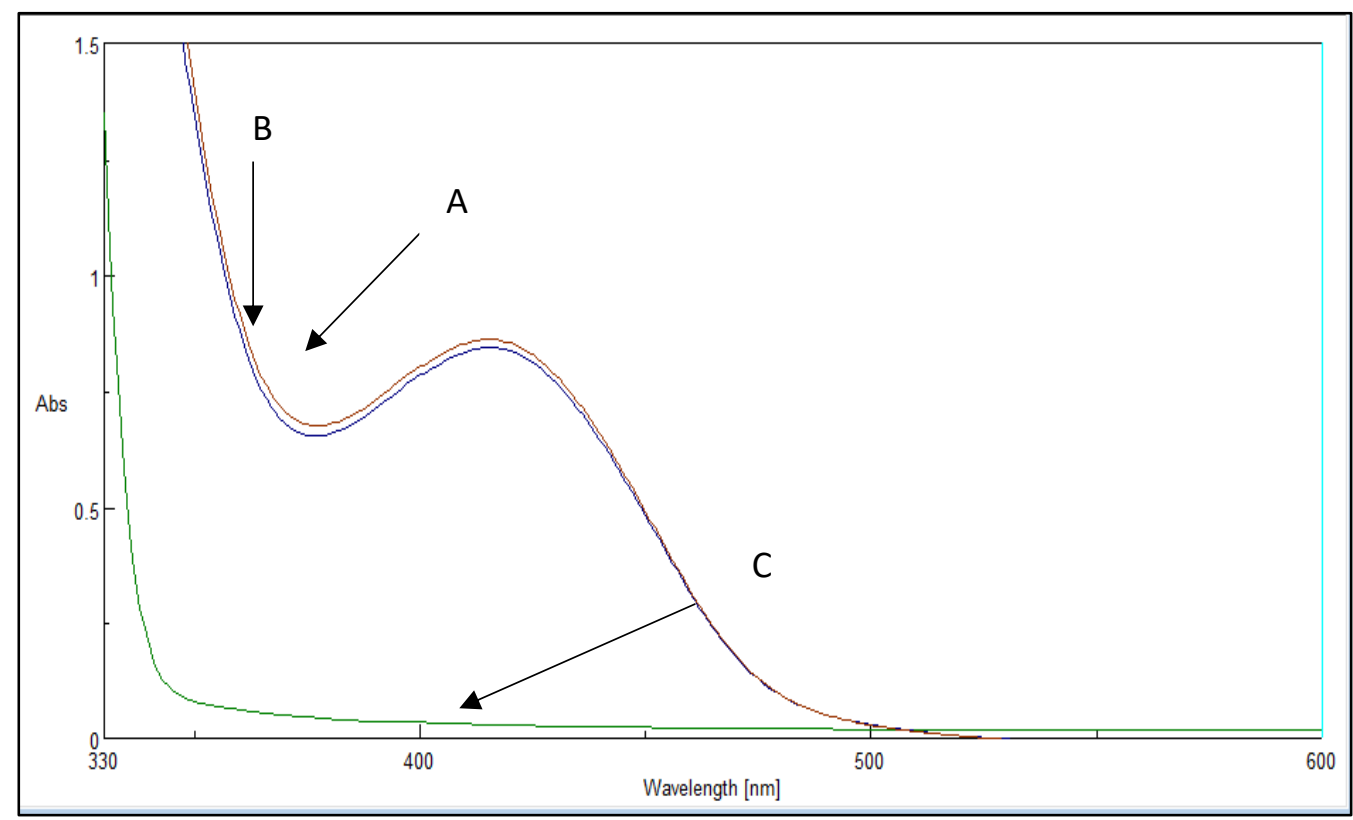

Fig.2.Absorption spectrum of: A-The AC-FA- aniline against blank ,B- AC-FA- aniline against distilled water. $C$ - Blank against distilled water

\section{Interferences}

The effect of various compounds on the estimation of $40 \mu \mathrm{g} \cdot \mathrm{ml}^{-1}$ aniline by using AC-FA reagent has been studied. The results were shown in table 3 .

Table 3: The Effect of Interferences.

\begin{tabular}{|c|c|c|}
\hline \multirow{2}{*}{ Compound } & \multicolumn{2}{|c|}{$\begin{array}{l}\text { Recovery of } 400 \mu \mathrm{g} \text { aniline / } \mu \mathrm{g} \text { amino compound in } 20 \\
\mathrm{ml}\end{array}$} \\
\hline & 500 & 1000 \\
\hline Atenolol & 103.13 & 99.18 \\
\hline 3-amino pyridine & 111.36 & 121.06 \\
\hline Isoniazid & 104.63 & 105.01 \\
\hline Histidine & 113.70 & 124.61 \\
\hline Nitrobenzol & 104.63 & 105.58 \\
\hline Resorcinol & 100.68 & 100.54 \\
\hline 4-Picoline & 102.86 & 105.17 \\
\hline Tri- methylamine & 103.72 & 104.83 \\
\hline Di-secondarybutylamine & 102.11 & 103.85 \\
\hline Sodium nitrite & 51.36 & 25.34 \\
\hline
\end{tabular}


The results illustrated in table 3 indicated that only 3-amino pyridine and histidine interfered in the determination of aniline by using AC-FA reagent according they are considered as primary amines. The results also show that the addition of sodium nitrite reduced the recovery of aniline which is due to the diazotisation of the amine group.

\section{The Application of The Method}

The suggested procedure has been applied in the determination of aniline in various samples of water by adding two amount of aniline 400 and $800 \mu \mathrm{g}$ in $20 \mathrm{ml}\left(20\right.$ and $\left.40 \mu \mathrm{g} \cdot \mathrm{ml}^{-1}\right)$ to $5 \mathrm{ml}$ of waters sample (tap, well and river waters). The results illustrated in table 4 included satisfactory recovery. This demonstrates the possibility of spectrophotometric estimation of aniline using ACFA reagent without interference of the studied water components.

Table 4: The Estimation of Aniline in Waters Samples.

\begin{tabular}{|c|c|c|c|c|}
\hline \multirow{2}{*}{$\begin{array}{c}\text { Water } \\
\text { sample }\end{array}$} & \multicolumn{2}{|c|}{$400 \mu \mathrm{g}$ in $20 \mathrm{ml}$} & \multicolumn{2}{|c|}{$800 \mu \mathrm{g}$ in $20 \mathrm{ml}$} \\
\hline & Recovery $\%$ & RSD \% & Recovery*\% & RSD \% \\
\hline Tap & 99.68 & \pm 0.75 & 100.51 & \pm 0.16 \\
\hline River & 100.34 & \pm 0.78 & 96.64 & \pm 0.88 \\
\hline Well & 97.63 & \pm 1.28 & 95.85 & \pm 0.51 \\
\hline
\end{tabular}

*Average of five determinations.

\section{The Comparison of The Methods}

Table 5 shows the comparison between some of analytical parameters obtained from the suggested method with those of other available spectrophotometric methods.

Table 5: The Comparison of The Methods

\begin{tabular}{|c|c|c|c|}
\hline $\begin{array}{c}\text { Analytical } \\
\text { parameter }\end{array}$ & Present method & Method in Ref.(21) & Method in Ref.(5) \\
\hline Reagent & Acetylacetone-formaldehyde & $\begin{array}{c}7,7^{\prime}, 8,8^{\prime} \text {-Tetracyano- } \\
\text { quinodimethane }\end{array}$ & $\begin{array}{c}2,6 \text {-Dihydroxy- } \\
\text { benzoic acid }\end{array}$ \\
\hline$\lambda_{\max }, \mathrm{nm}$ & 417 & 323 & 432 \\
\hline $\mathrm{pH}$ & 4.3 & 6.02 & 10.36 \\
\hline Linearity & $2.5-50$ & $0.5-2.5$ & $0.2-3.2$ \\
\hline Temperature & $40^{\circ} \mathrm{C}$ & $\mathrm{R} . \mathrm{T}$ & $\mathrm{R} . \mathrm{T}$ \\
\hline $\begin{array}{c}\text { Molar absorpitivity } \\
\text { L.mol. }{ }^{-1} \text { cm. }\end{array}$ & $3.864 \times 10^{3}$ & $1.72 \times 10^{4}$ & $4.2 \times 10^{4}$ \\
\hline RE\% & -4.16 & +1.7 & +1.13 to +4.4 \\
\hline RSD\% & $< \pm 1.29$ & $< \pm 3.69$ & $< \pm 0.77$ \\
\hline Application & Water samples & $\ldots \ldots \ldots \ldots \ldots$ & Water samples \\
\hline
\end{tabular}

The results illustrated in Table 5 show that the present method has good sensitivity, but the diasotisation and charge transfer methods are more sensitive. 


\section{Conclusion}

A direct and simple spectrophotometric method for the estimation of aniline in various water samples was done. The method doesn't need any step of separation of aniline from its water samples . The method can be considered a sensitive method depending on the good molar absorpitivity value.

\section{References}

1. Thomas K., Lawrence F. R., Marshall W. J., Höke H. and Jäckh R. "Aniline in Ullmann's Encyclopedia of Industrial Chemistry", John Wiley \& Sons, New York(2007).

2. Bashir W. A. and Othman N. S. J.Edu.Sci., 16: 97-107 (2004).

3. Othman N. S. and Hamdoun E. A., Raf.J. of Sci., 16: 60-67 (2005).

4. Othman N. S. and Othman N. H.,Raf.J. of Sci.,24: 42-51 (2013).

5. Othman N. S. , Hamdoun E. A. and Sultan S. H. J.Edu.Sci., 18:24-32 (2006).

6. Wilcox RW. Medical News, 15(77):931-932 (1900).

7. Benigni R. and Passerini L., Mutat. Res., 511: 191-206 (2002).

8. Brede C., Skjevrak I. and Herikstad H., J.Chromatogr. A., 983:35-40 (2003).

9. Reddy-Noone K., Jain A. and Verma K.K. Talanta, 73: 684-691 (2007).

10. Sarafraz-Yazdi A. and Es'haghi Z. Talanta,66:664-669 (2005).

11. Zhao L. M., Zhu L. Y. and Lee H. K. J. Chromatogr. A, 963:: 239-248 (2002).

12. Patsias J. and Papadopoulou E.,.J. Chromatogr. A, 904:171-188 (2000).

13. Yang.H. and Weisz A., J. of AOAC Inter., 101( 6): 1961-1966 (2018).

14. Shuhui L. W., Chen J. and Sun J., Int. J. Mol. Sci., 13: 6863-6872 (2012).

15. Sun Y., Liang L., Zhao X., Yu L., Zhang J., Shi G. and Zhou T., Water Res. 43:41-46 (2009).

16. Meiping Z. , Yang X. , Yuanzong L., Zhang X. and Wenbao C., Inter. J. Envir. Anal. Chem. , 223-230 (2006).

17. Kornepati1S. and Divakar E., Rasayan J.Chem. 8 ( 3):,373 - 379 (2015).

18. Amlathe S. and Gupta V.K. , Microchemical Journal, 43( 3) : 208-212 (1991).

19. Al-Abachi M. Q., Al-Ghabsha T.S. and Salih E.S. , Microchemical Journal 41(1): 64-71(1990).

20. Wu H. and Dul M., Spectrochimica Acta. Part A, Molecular and Biomolecular Spectroscopy, 67(3-4):976-979(2006) .

21. Al-Sabha Th. N. and Al-KaremN. M. y, J. of Analytical. Methods in Chemistry., 8 (2013).

22. Rani P. A., Sekaran C., Kumar K. and Ramesh A., Chem. Sci. J., 1-10 (2012). 
23. El-Hamda M.A., Alia R. , Haredy A. M., Ahmedc H.M., Derayeab S. M. and Abdelmageed O. H., J. Applied Pharma. Sci., 7 (02) :147-155(2017).

24. Nagaraju C., Gorla R., Kumar U., Nagasrinivas K. , Hemant S. and Vidavalur S. ., Inter. J. Pharma. Sci. and Res.,17(2):834-838 (2016).

25. El-Yazbi A. F., Guirguis K. M. , Bedair M. M. and Belal T. S.. Heliyon, 5: 1-10 (2019).

26. Elazazy M. S.,RSC Adv., 60: 1-10 (2015).

27. Amin A. S. and Zareh M.M.,Microchimica Acta, , 124( 3-4): 227-233(1996). 